ELORE (ISSN 1456-3010), vol. 17 - 2/2010.

Julkaisija: Suomen Kansantietouden Tutkijain Seura ry.

[http://www.elore.fi/arkisto/2_10/palmgren_2_10.pdf]

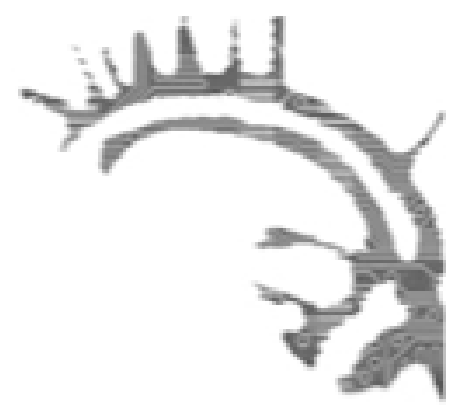

\title{
RECENSION
}

\section{IDENTITETSMÖJLIGHETER I BEKÖNAD SJÄLVSKADEHANDLING}

JOHANSSON, ANNA 2010: Självskada. En etnologisk studie av mening och identitet i berättelser om skärande. Umeå: Bokförlaget h:ström - Text \& Kultur. 308 sidor.

\section{Ann-Charlotte Palmgren}

Jag satt i ett café tillsammans med en manlig bekant. Det var andra gången vi träffades, gången innan hade han berättat att han lider av panikattacker. Han vilade sina armar på cafébordet, hade stickade pulsvärmare runt sina handleder. Jag noterade dem, främst för att de hade dödskallar på sig och matchade hans tröja. Han tog bort dem en stund och visade sina handleder. "Jag har dem bara för att de är snygga. Inte för att dölja”, sa han. Jag nickade men förstod först långt senare vad han egentligen menade med det han sa.

Innan jag satt vid cafébordet hade jag många gånger läst om att skära sig och olika former av självskada, men samtliga gånger hade jag kommit i kontakt med fenomenet på nätet. "Att skära sig medvetet med vassa föremål är ett tecken på att man inte mår bra. För att bryta ångesten och depressionerna måste man söka vård. Terapi och läkemedel är två behandlingsmetoder." Citatet hittas på nätet i Stockholms läns landstings Vårdguiden, under rubriken "Skära sig". Senare fortsätter texten med "Du som självskadar dig är troligen en yngre kvinna. Självskador är upp till fyra gånger vanligare hos flickor än hos pojkar.” De allra flesta av dem som Anna Johanssons doktorsavhandling handlar om är unga tjejer och relationen mellan självskada och kön är ett genomgående tema i avhandlingen.

\section{ATT TA SIG AN BERÄTTELSER OM SJÄLVSKADA}

Avhandlingens övergripande syfte är att undersöka hur unga människor som skär sig själva tillskriver självskadandet mening genom att skriva om det på nätet och 
tala om det i intervjuer. Centrala begrepp i Johanssons doktorsavhandling är mening, betydelser, konstruktion och identitet. Materialet som avhandlingen baserar sig på är mycket digert: intervjuer, forumdiskussioner på nätet, litteratur och medierepresentationer. Att materialet är så digert kunde uppfattas som problematiskt eftersom risken då finns att en möjlighet till fördjupning i ämnet går förlorad. Detta undviker Johansson. Avhandlingens utgångspunkt är att diskussionsforum på nätet liksom intervjuer utgör arenor där fenomenet skärande skapas och Johansson har valt att se intervjuerna och forumdiskussionerna som sitt huvudmaterial, vilket även kan ses i dispositionen där analysdelen av avhandlingen inleds med ett kapitel där endast litteratur och media diskusteras medan intervjuerna och nätdiskussionerna får betydligt större utrymme i de följande kapitlen. Att litteraturmaterialet och mediarepresentationerna beskrivs och analyseras i ett inledande och avskilt kapitel gör att det kan ses som en introduktion till ämnet självskada. Samtidigt kan läsaren se att informanternas berättelser och diskussionsinläggen i nätforumen har blivit influerade av till exempel existerande självbiografisk litteratur och Socialstyrelsens publikationer. Även om studien är kvalitativ kan den ses som kvantitativ när det gäller medierepresentationerna. Genom sökningar och antalet träffar under olika år visar Johansson hur det ter sig som om självskadande handlingar plötsligt fick ett nyhetsvärde år 2003.

Som Johansson inleder sitt metodkapitel kan det vara en stor utmaning att i en kvalitativ analys beskriva tolkningsprocesser och tillvägagångssätt, något som Johansson däremot gör mycket grundligt och förtjänstfullt. Samtidigt framkommer hur Anna Johansson kategoriserat forummaterialet i följande fyra kategorier: kropp, känsla och skärandehandlingen; hjälpsökande och pratets betydelse; trovärdighet, autenticitet och kulturella tillhörigheter samt patientskap och relationen till psykiatrin. Dessa kategorier återkommer även i dispositionen som skilda kapitel.

\section{SJÄLVSKADA I RELATION TILL KROPP, KÖN OCH IDENTITET}

Begreppet självskada förutsätter någon som skadar sig själv, alltså ett subjekt. Subjektet får stort utrymme i Johanssons avhandling. I relation till detta diskuteras identitet, identifikation, patienskap, aktörskap och offerskap genomgående i doktorsavhandlingen och begreppet autenticitet blir ett mycket viktigt begrepp för den person som skadar sig själv och sedan berättar om det. Det handlar inte endast om autentiska berättelser, utan om autentiska identiteter.

Även om självskada kan ses som något väldigt kroppsligt, får själva kroppen inte så stort utrymme i Johanssons doktorsavhandling. Kroppen och självskada kopplas ihop med önskan om kontroll, att fördriva det onda, lätta på trycket. Ett dåligmående som kan ses som något kroppsligt ses här som en identitet. Ärren på huden ses som identitetsmarkörer.

I citatet $\mathrm{i}$ inledningen av recensionen nämns det i Vårdguiden för Stockholms läns landsting att självskador är fyra gånger vanligare bland flickor. Och även om kön är 
ett genomgående tema i avhandlingen skriver Johansson att frågor om kön i intervjuerna nästan enbart diskuterades då Johansson själv lyfte up detta. I nätforumen är de självskadande flickorna normen och därmed tycks kön inte explicit diskuteras om det inte är fråga om en självskadande pojke uppmärksammar eller ifrågasätter normen.

Johanssons doktorsavhandling är förtjänstfull på många sätt. Den är välskriven, har en tydlig disposition, materialet är mångsidigt, berättelserna och utdrag från dem får plats samtidigt som fokus ligger på Johanssons egen analys av dem. Temat självskada är ytterst aktuellt och samtidigt kan flera paralleller dras till andra fenomen i det västerländska samhället och kulturen, till exempel hur flickor och även pojkar i viss mån skriver om ätstörningar i diskussionsforum på nätet. Även om det är fråga om en doktorsavhandling anser jag att såväl forskare som studenter har behåll av boken, för att inte nämna personer som arbetar med ungdomar på olika sätt.

Filosofie magister Ann-Charlotte Palmgren är doktorand i kvinnovetenskap vid Åbo Akademi. 